\title{
Depoliticised ethnicity in Tanzania: a structural and historical narrative
}

\author{
Mrisho Malipula \\ Mzumbe University, Tanzania
}

\begin{abstract}
Much of the literature on ethnicity in Africa regards ethnicity as a central cleavage and associates its politicisation with civil war and deteriorating socio-economic conditions. Tanzanian society is not structured by this cleavage, making it an outlier among African states. Despite the negative impact of politicised ethnicity, little is known of the circumstances through which it germinates and comes to have negative consequences, or how it can be suppressed in Africa. The present article attempts a comprehensive analysis of the structural and historical factors that have made the move away from politicisation of ethnicity in Tanzania possible. It provides an eclectic structural and historical explanation that attributes lack of ethnic salience in Tanzanian politics to a particular ethnic structure, to certain colonial administrative and economic approaches, and to a sustained nation-building ethos. The argument results from a critical analysis of secondary material on ethnicity and the politics of Tanzania.
\end{abstract}

Key words: ethnicity, politicisation of ethnicity, ethnic salience, nation-building, Tanzania

\section{Introduction and argument}

Tanzania ${ }^{1}$ is an African state that exhibits a striking plurality of ethnic groups which, unlike inmany other African States, are not ethnically politicised ${ }^{2}$ (Bratton et al. 20II; Weber, 2009). Tanzanians are less ethnically politicised 'despite' having around I20 ethnic groups (Jerman, I997:34). That Tanzania is not structured on this cleavage is, so to speak, 'abnormal' for an African state. Although the seminal study by Fearon and Laitin (2003) has warned about blaming inter-group conflicts on ethnicity, demonstrating that most civil wars have had economic rather than ethnic grounds, the ethnic cleavage is widely associated with obstructed welfare. The overriding literature on ethnicity in Africa

Tanzania is a United Republic formed as the result of a merger between the previously sovereign Tanganyika (officially called Tanzania Mainland) and Zanzibar states in I964. The scope of the current article is Tanzania Mainland, therefore for this article Tanzania refers to one side of the merger-Tanzania Mainland/Tanganyika unless stated otherwise in the article. Issues of Zanzibar that contrast Tanganyika's experience on ethnic salience in politics will only be described briefly.

2 Ethnicity conventionally stands for one's belonging to a social group with ethnic traits. Politicised ethnicity in this article refers to a politically oriented consciousness of that ethnic belonging, hence active ethnic identities engaged in political affairs. 
purports that ethnic diversity counteracts development initiatives or that countries with such diversities are expected to experience low macro-economic stability and diminishing growth rates, corruption and poor public services (Miguel, 2004:327).

A number of voices in recent research express the idea that ethnic diversity presents economic advantages to diversified states (Collier, 2009:59). Collier's argument is anchored on the assumption that ethnic diversity presents an opportunity for raising diverse productivity skills and knowledge useful for problem solving. It is a moot question, however, whether politicised ethnicity would provide the same advantage. In other words, not every type of ethnicity affords the same opportunities. Similarly, a third strand of ethnicity studies, consisting of authors linking ethnicity to the emergence of civil conflicts in Africa (Lemarchand, I994; Cederman \& Girardin, 2007), has failed to offer an unequivocal assessment of ethnicity's impact on the continent.

More specifically, the three strands of literature fall short of explaining why ethnically heterogeneous countries like Tanzania that have not experienced civil war, a country whose economic problems cannot be attributed to ethnic diversity. While there is still little debate in this area, it is probably these nagging ambiguities that have informed a new line of thinking that focuses on the politicisation of ethnicity, rather than ethnic diversity, and associates negative effects therewith (Miguel, 2004; Posner, 2005). This line of thought is guided by the definition of politics as who gets what, when and how; also known as the authoritative allocation of resources. The definition translates ethnic salience into ethnic favouritism in the allocation of public resources, which includes low inter-ethnic cooperation, leading to social and political grievances among ethnic groups (Posner, 2005; Miguel, 2004). We argue that despite its 120 ethnic groups, all socially identifiable through some unique features of their languages and their cultures, Tanzanian society and its cultural diversity have not been politicised to the point of limiting inter-ethnic cooperation. Importantly, this is true in all of its 4 major historical epochs: Pre-colonial, Colonial, Post-independence, during the socialist nation-building phase, and the liberalisation era. Thus we can conclude that Tanzania is ethnic only socially and culturally, not politically (Lupogo, 200I; Nyang'oro, 2004).

While much has been documented on the negative impact of ethnicity and its politicisation in Africa as sketched in above, little is known of the circumstances through which ethnicity germinates as a politically salient identity and grows to become a debilitating force. Also, the question of how it can be suppressed for the purposes of national unity remains an issue. Knowledge of the causes of the politicisation of ethnicity is mainly limited to a country's ethnic structure - the number and size of ethnic groups (Barkan, I994; Posner, 2005). According to this line of thought countries with few and large ethnic groups are expected to be more ethnically politicised as they are endowed with ethnic groups large enough to form a minimum winning coalition ${ }^{3}$ in elections. The contrary is viewed to be true for countries with an array of small ethnic groups, a situation that forces political parties to reach out to, and win votes from, a myriad of ethnic groups through national 
programs (Weber, 2009:2).Tanzania would seem an instance of this kind of electoral process; and it helps to explain the lower levels of ethnic politicisation in the country.

As convincing as the ethnic structure explanation may be at first glance, it is not immune to criticism. The leading criticism comes from the political ethnographic school which questions the validity of the structural argument on the grounds that the dynamic and contextual reality of ethnic identities renders useless any static conceptualisation of ethnic structures and their politicising effect (Schultz, I984). Moreover, against both the ethnic structure argument and its critique, Miguel (2004) suggests that nation-building policies and practices can moderate ethnic politicisation. To Miguel, nation-building can mitigate politicisation of ethnicity, while lack of the same can exacerbate it.

Tanzania stands as a positive example in both the ethnic-structure and nation-building debate. This is chiefly because it is recognised as a state in which ethnicity is not politically salient despite being ethnically diverse. Specifically in electoral terms, the size of even the largest ethnic groups can barely constitute the minimum for achieving a winning coalition, as this article will show. Similarly, Tanzania has embarked on a sustained nation-building project from colonialism to-date. The current analysis of the causes of politicisation of ethnicity in Tanzania by Weber (2009) comparing Tanzania and ethnically salient Kenya supports the nation-building argument, even to the point of dropping the structural argument altogether. Weber holds the view that Tanzania through the Sukuma 4 has the potential to mobilise a "super tribe" and forge the minimum winning coalition to render the structural explanation irrelevant. Hence, lack of ethnic salience in Tanzanian politics should not be attributed to the number (structure) of its ethnic groups but to nation-building policies, with the addition of two related factors: its colonial history and lack of land alienation. We go partly against and beyond Weber by arguing that the lack of ethnic salience in Tanzania's politics can be explained by a complementary blend of structural and historical factors, the latter including pre-colonial, colonial and post-colonial facts, as well as the current sustained quest for unity and peace under the ongoing era of political and economic liberalisation.

The over-arching argument presented in this article is the product of an in-depth path-dependence analysis. We describe the structural and historical factors responsible for the movement away from the politicisation of ethnicity in Tanzania. The article in the main re-affirms the ethnic structure argument for politicisation of ethnicity rejected by Weber. But to comprehend the process we also establish the role of pre-colonial ethnic identities and colonial administrative approaches, anti-colonial nationalistic movements and the post-colonial socialist nationbuilding policies and practices. It further analyses the role of a sustained enthusiasm for unity and peace amid economic and political liberalisation, on ethnic depoliticisation in Tanzania. Upon completion of the discussion we will obtain an eclectic structural and historical explanation of the causes of the lack of ethnic salience in Tanzanian politics. The article is based on a critical analysis of detailed historical information from the pre-colonial era to-date and draws on extensive archival and other secondary material on ethnicity and politics of Tanzania. 


\section{Methodological and analytical underpinnings}

This article subscribes to the view that national "political culture"s does not emerge overnight. Instead it is built and toughened over decades. In this regard, national values, institutions and practices that set a country away from ethnic salience in politics are consciously drawn from a nation's do's and don'ts. It is against this backdrop that we employ James Mahoney's model of path dependence that argues that antecedent historical conditions make certain policy decisions more likely than others. From this background depoliticised ethnicity could be attributed to the path set by pre-existing demographic, economic, societal, and political situations (Mahoney, 2001:6). Mahoney's thesis, which we agree with, is that structures and processes inform and reinforce eachother in shaping outcomes or choices. Once these choices are made, Mahoney argues, states tend to remain on the chosen path because values and institutions associated with them become self-perpetuating and political elites sustain values and institutions that benefit them. Moreover, political elites and the organs of governance commit themselves to values and institutions upon which they have staked their reputations, and therefore they cannot afford to establish new ones. As for citizens, accepted values and institutions are viewed as legitimate, and thus they voluntarily opt for their reproduction based on the conviction that it is the right thing to do (Mahoney, 2001:9). A classic comparison, in economics, is with production units sticking together out of the need for cost-efficiency (also known as the power law) and then naturally growing into a hub (which may acquire a particular outlook or 'culture'). In Tanzania, the afore-mentioned Sukuma is historically a conglomerate of several ethnic groups that (for whatever cost-benefit advantages such as protection and subsistence) gradually blended into a common cultural body, without the whole or the parts ever being politicised as such.

Focusing in on the path-dependent framework we trace how lack of ethnic salience in politics is informed by the pre-colonial ethnic structures and processes, the divisive and exploitative colonial structures that necessitated a united fight among the oppressed during the nationalistic struggles, and later the socialist nation-building project which equitably distributed economic gains and fought discrimination of all kinds. Further, we look into how the past informs the choice of national as opposed to ethnic identities in politics in the present liberalisation era. We speak in particular of depoliticised rather than unpoliticised ethnicity, since the latter would imply the lack of a process, and we argue that the absence of politicised ethnicity is in fact the result of a process, one that is historical and ongoing. In essence we are tracing the long-term path of national identity responsible for the continued pacifying frame against divisive agendas within the contemporary era of liberalised economics and politics in Tanzania, which are characteristically different from the pre-liberal political orders. This objective tests the authenticity of Mahoney's contention that "path-dependent structures and institutions endure in the 
absence of the processes that initially led to their establishment" (Mahoney, 200I:9). The subsequent part of the article presents and analyses ethnic depoliticisation in Tanzania.

\section{Explaining the depoliticisation of ethnicity in Tanzania \\ Reaffirming the Ethnic Structure Argument}

As indicated earlier, explanations for the germination of ethnicity as a politically salient feature in a country is attributed to, among other factors, the number and size of ethnic groups in a country (Posner, 2005 ; Barkan, I994). According to this view ethnic structures can result in two opposing outcomes of an ethnic salience polity continuum positive and negative (Bates, I983:I64-I65). In this regard, countries with few and large ethnic groups are expected to be more ethnically politicised as these ethnic groups are large enough to win a majority in elections. Since the base of support is an ethnic group, once politicians acquire political power, they distribute resources favourably to their co-ethnics. The contrary is viewed to be true for countries with an array of small ethnic groups which forces politicians to reach out to, and win votes from, a myriad of ethnic groups nationally. Under such circumstances politicians strive to sustain an ethnically inclusive posture by equitably distributing the spoils of the state (ibid.).

It is important to note that the ethnic structure explanation of politicisation of ethnicity is criticised by political ethnographic scholars on the grounds that it neglects the dynamic and contextual character of ethnic identities (Shultz, I984). To this school of thought, the structural argument's neglect of the dynamic and contextual nature of ethnic identities is a serious flaw as ethnic groups might be re-grouped into smaller sub-tribes or larger super-tribes (Weber, 2009:8). In this respect, then, the structural explanation is only relevant to static ethnic structures and well defined ethnic groupings. Where does the Tanzanian case fit in this broad structural debate?

Tanzania exhibits a striking plurality of ethnic groups. Estimates differ, but 120 is the most quoted figure of ethnic groups in the country (Jerman, I997:34). However, some estimates put the figure as high as I50 (Omari, I997:5I) while others (Nyang'oro, 2004) indicate $\mathrm{I} 30$ and yet others I4O (Heilman and John, 20I2:2). The task of providing an official number of ethnic groups and of their population size is greatly hindered by the 1967 legal prohibition on registering the population on the basis of ethnic groups and religion (Jerman, I994:34). Nevertheless, estimates can be found in the literature. Glickman I995 present estimates of the seven largest ethnic groups in the country by I992. Likewise, the Afrobarometer ${ }^{6}$ surveys of 2005, 2008 and 20I2, which list the ethnic origin of its respondents, also sheds light on the size of ethnic groups. Although the sample size of

6 Afrobarometer is an independent, non partisan research project that conducts regular surveys measuring social, political and economic atmosphere in around 20 African countries. The main partners are the Centre for Democratic Development (CDD-Ghana), The Institute of Democracy in South Africa (IDASA), Institute of Empirical Research in Political Economy (IREEP) and the Institute of Development Studies (IDS) University of Nairobi. These partners are provided technical support by the Michigan State University and The Democracy for Africa Research Unit (DARU), Centre for Social Science Research, University of Cape Town. Likewise in all nations there are national partners who oversee data collection exercise. For Tanzania REPOA (Research for Poverty Alleviation) is responsible. 
the surveys ( $\mathrm{N}=\mathrm{I} 208, \mathrm{~N}=\mathrm{I} 304$ and $\mathrm{N}=2004$ for the 2005,2008 and 2012 surveys) might be viewed as too small to give reliable estimates for the whole Tanzanian population, there is at present no better alternative to establishing ethnic group size. Based on these sources, the seven largest ethnic groups in Tanzania can be listed as follows.

\begin{tabular}{|c|c|c|c|c|c|}
\hline $\begin{array}{l}\text { Ethnic } \\
\text { Groups }\end{array}$ & $\begin{array}{c}\text { I967 } \\
\text { Census }\end{array}$ & $\begin{array}{c}1992 \\
\text { Estimate }\end{array}$ & $\begin{array}{c}\text { Afrobarometer } \\
2005\end{array}$ & $\begin{array}{c}\text { Afrobarometer } \\
2008\end{array}$ & $\begin{array}{c}\text { Afrobarometer } \\
2012\end{array}$ \\
\hline Sukuma & $\mathrm{I} 2.4 \%$ & $14 \%$ & $\mathrm{I} 6 \%$ & $17 \%$ & $14 \%$ \\
\hline Nyamwezi & $3 \cdot 3 \%$ & $8 \%$ & $4 \%$ & $4 \%$ & $4 \%$ \\
\hline Chagga & $3.6 \%$ & $6 \%$ & $5 \%$ & $3 \%$ & $5 \%$ \\
\hline Makonde & $3.9 \%$ & $6 \%$ & $2 \%$ & $3 \%$ & $3 \%$ \\
\hline Haya & $3.3 \%$ & $6 \%$ & $4 \%$ & $2 \%$ & $2 \%$ \\
\hline Hehe & $\mathrm{N} / \mathrm{A}$ & $6 \%$ & $3 \%$ & $2 \%$ & $3 \%$ \\
\hline Nyakyusa & $\mathrm{N} / \mathrm{A}$ & $5 \%$ & $3 \%$ & $2 \%$ & $2 \%$ \\
\hline TOTAL & $26.5^{+}$ & 51 & 37 & 33 & 33 \\
\hline
\end{tabular}

Table 1. Relative Size (\%) of Ethnic groups in Tanzania (Sources: 1967 Census Tanzania; 1992 estimate figures based on Glickmann (1995: 308); Afrobarometer Tanzania 2005, 2008 and 2012

The figures presented above indicate that Tanzania is an ethnically diverse state without an ethnic group close to commanding a simple majority in presidential elections. More importantly, such status could not even be achieved by a merger of the large ethnic groups as they constitute only around $37 \%$ of the general population. ${ }^{7}$ Under such circumstances, grand coalitions based on ethnic group sizes could be beneficial to the smaller groups as their mergers can produce a minimum winning coalition. But regardless, the minimum winning majority requires massive canvassing in Tanzania. This structural fact provides an incentive to nationalistic political canvassing as any ethnic move must be ethnically broad and inclusive to have a positive effect. It is against this background that Barkan (I994:I0), Hyden (I994:79) \& Glickman (I995:289) partly attribute the lack of ethnic salience in politics in Tanzania to its ethnic composition. However, Weber (2009:7) refutes the contention by making the contrast with its neighbouring country Kenya. Although Kenya lacks an ethnic group with clear majority, ethnicity has long played a significant role there to the extent that presidential elections resemble an ethnic census (Bratton and Kimenyi 2008; Barkan I994).

The argument advanced by Weber against the structural explanation of ethnic salience is predicated on the assumption that Kenya and Tanzania have the potential to forge 
minimum winning coalitions. For instance, in Kenya ethnic groups competing for power and resources are blocs made up of smaller groups appearing as one on the national political scene (Kiondo, 200I:260-6I). The Kalenjin which was crafted by President Moi by combining his own small Tugen and other cousin ethnic groups (Nandi, Kipsigis, Elgeyo, Marakwet, and Pokot) to support his presidential bid, provide an example of how the politicisation of ethnicity can originate from a small tribe (Weber, 2009:8). The Kikuyu's inclusion of the cousin tribes of Embu and Meru to increase their number from $21 \%$ to $27 \%$ provides an example of a large tribe extending itself for political reasons (Ibid.). There are also politically motivated ethnic mergers like the Luhya and Mijikenda (Makoloo, 2005:II) as well as the Masai and Samburu (Ogot, 2005:29I). Taking into consideration the Kenyan examples where tribes have come together irrespective of their sizes, Weber wonders why the Sukuma have not made use of their numerical advantage to maximise their political influence. To Weber the explanation cannot be found in their size. While this idea might well attract support, we believe that it is open to criticism.

The critique, salvaging aspects of the hypothesis of a structural politicisation of ethnicity, is anchored in the fact that the major ethnic groups in Kenya (Kikuyu, Luo, Luhya, Kamba \& Kalenjin) do provide incentive for ethnic politics as their numbers combined is above the minimum winning coalition. ${ }^{8}$ More precisely, if the leading ethnic groups in Kenyan politics - the Kikuyu and Luo - manage to court two big and a few smaller groups they can compose a minimum winning coalition. ${ }^{9}$ This is not the case in Tanzania where the Sukuma and Nyamwezi together constitute less than $25 \%$ of the general population and where none of the other II 8 tribes has more than $4 \%$ of the general population as indicated above. Under such circumstances, the Sukuma-Nyamwezi conglomerate would need to embark upon pan-territorial courting of ethnic groups in order to achieve success.

We also question the relevance of Weber's choice of the Kalenjin to argue his case. We agree that President Moi has engineered the formation of the Kalenjin and used it for political visibility, but by no means has it guaranteed him the minimum winning coalition. He came into power without elections as he succeeded President Jomo Kenyatta, who died in the middle of his term. Moi clung to power through the political infrastructure built by Kenyatta and utilised the advantages of his incumbency (Mutua, 2008:66). The advantage included the misuse of coercive organs to intimidate his opponents to the extent that his re-election under multi-party politics was regarded as fraudulent (Brown, 200I; Klopp, 200I). President Moi only managed to elevate the Kalenjin into an important bloc by supporting the two major political bases in Kenya, the Kikuyu and Luo, thus coaxing the ruling or opposition circles depending on the electoral outcomes. This potential, activated by Moi, may be structurally informed by the fluidity of the Kenyan tribes and real potential of making the minimum winning majority. constituting 24.6 million. The distribution being Kikuyu: $6.6 \mathrm{~m}$ Luhya: 5.3m, Kalenjin: 4.9m, Luo: $4 \mathrm{~m}$ and the Kamba: $3.8 \mathrm{~m}$.

9 Assuming all are eligible to vote the minimum winning coalition requires I9.3 million which could be met if the Kikuyu,Luhya and Kalenjin plus Kikuyu's cousins Embu and Meru joined. 
The general argument concerning Tanzania contrasts to the situation in Zanzibar. This is because the geographical division of the Islands constituting Zanzibar-Pemba and Unguja presents an ethno-regional structure potentially close to making a minimum winning coalition. The division manifested in the Wapemba vs Waunguja divide with the former predominantly supporting Civic United Front (CUF) and the latter the ruling Chama Cha Mapinduzi (CCM). The division is clear and replicates in all multiparty elections in Zanzibar despite overt attempts to reverse the pattern by the competing parties canvassing pan-territorially (Nyaluke, 2013).

The structural explanation for depoliticisation of the ethnicity in Tanzania is not limited to the presidential race. The situation is also vividly apparent in parliamentary and civic elections as the demarcation of most of the parliamentary and civic electoral constituencies particularly found in rural areas are predominantly occupied by one ethnic group (Nyaluke, 2013). The lack of divided ethnic groups in these constituencies principally restrains the potential for inter-ethnic conflicts as contestants are from the same ethnic group. Potentially intra ethnic conflicts could occur as ethnic groups are composed of different clans, but, there is no evidence to claim its salience in Tanzanian politics (ibid.). Only Dar es Salaam, the commercial capital of Tanzania is ethnically cosmopolitan to present an exception to constituencies' ethnic group homogeneity. Other urban constituencies share Dar es Salaam's cosmopolitan nature yet the ethnic groups inhabiting the cities or towns are often more populous than the immigrants, thus dampening the efficacy of politics centred around the original inhabitants against immigrants (ibid.).

Generally speaking, the potential for politicisation of ethnicity suggested by Weber is, in the case of Tanzania, imaginary. The obstructions are not only structural but also exist at the level of political ethnic consciousness. Ethnic groups in Tanzania have socially active and identifiable traits that resist political manipulation. Also the scale of ethnic diversity and the distribution of tribal populations makes political manipulation difficult to execute; and attainment of the minimum winning coalition by default ensures, as argued above, a national rather than ethnic outlook. Because of both the numerical argument for acquisition of state power and the crystallised nature of the ethnic groups, the structural element still has a part to play in the explanation of depoliticised ethnicity in Tanzania, the exceptions of the Dar es Salaam and Zanzibar cases notwithstanding. Rather than asking whether or not it has a role in mitigating such politicisation, the question should be to what extent does it do so... Therefore we complement the structural argument by turning to history, the path(s) of the past, and consider the ethnic structure in place since the pre-colonial administration until the current administration. Also in order to clarify why the structure has been retained and taken advantage of to unite Tanzanians against ethnic salience in politics, a thoroughgoing historical perspective is required. 


\section{History}

Pre-colonial legacy

Most of the ethnic groups in Tanzania during the pre-colonial era were non-centralised, based on kinship and clans (Wemba-Rashid, I975:I0). There were only a few societies with high community social formations that developed centralised state systems such as the Chagga, the Hehe, the Ngoni, the Gweno, the Nyamwezi, the Shambaa and the Sangu (Mpangala, I999). The literature on ethnicity in African countries converges on ethnic identities being fluid, characterised by porous and constantly redefined boundaries (Berman, I998:310-I2; Chabal 2009:32-33). The redefinition of the groups was a product of continuous processes of inward migration and societal conquests which led to the amalgamation of social and language groups into bigger ethnic groups (Iliffe, I979:8). Such ethnic amalgamations diffused the original traits of the parties to the mergers and the base of authority of the chiefs of the artificial amalgamations.

The pre-colonial history of Zanzibar provides an antithesis to that of Tanganyika as the Oman Sultanate in the Igth century established a highly centralised state in Zanzibar (Mpangala, I992). The centralised political system under the Sultanate was founded around the slavery mode of production that divided people in slaves and slave masters. The political system of pre-colonial Zanzibar and its associated economic mode had implications for its ethnic structures. The structures became manifest in terms of class and race whereby the Oman Arabs constituted the ruling class and the land-owning aristocracy, the Indians were the traders and financiers of the slave trade while Africans, mainly from Tanganyika, constituted the class of slaves - the indigenous Zanzibari Africans and the Shirazi ${ }^{\text {Io }}$ people were mere peasants (Mukangara, 2000). At this juncture we can agree with Bakari (200I) who argued that even before colonialism the elements of racial and class-related ethnicity in Zanzibar were developed that we still see today. However, a detailed discussion of Zanzibar is, as indicated above, beyond the scope of this study.

Interestingly, studies on political formation in the great lake region indicate that societies with feudal and centralised kingdoms did by the igth century show greater tendencies of ethnicity and ethnic conflicts during the post-independence period compared to the less centralised kingdoms, despite processes of creation and consolidation of ethnicity under colonialism (Mpangala, I999). Tanzania augurs well in Mpangala's observation as ethnicity has not been a cause of conflict in less centralised Tanganyika, in contrast with centralised Zanzibar where politicised racial (Arabs vs Africans) and regional (Pemba vs Unguja) divides have continuously triggered conflicts (Mukangara, 2000; Bakari, 200I). Did this trend characterise the colonial epoch?

Io The Shirazi are a sub group of the Swahili people living on the Swahili coast of East Africa especially in Zanzibar and Comoro. Literature indicates that the Shirazi people are descendants of slaves originating mainly from Persia and others from the Somalia and Comoro. 


\section{The colonial epoch}

\section{Colonial German Tanzania (1985-1920)}

The German colonialists, who established their authority over Tanganyika in I895, instituted a direct administrative order that weakened the political and economic structures of pre-colonial Tanzanian societies. The German colonialists discriminated against all Black Africans in favour of European and Asian interests (Klugman et al., I999:77). The direct rule essentially accorded foreigners the realm of political control of the colonial administration at all administrative levels (Iliffe, I979:II8). This had the effect of diffusing ethnic belonging, because the leaders did not stem from the ethnic groups they led; they spoke Swahili as opposed to the local vernaculars. There were also areas in which the Germans employed semi-indirect rule rather than use their own administrators (Mpangala, I999:I3). Under "semi-indirect" rule, the Germans used ethnic chiefs to further their interests but stripped them of most of their traditional powers and in some instances changed their traditional names. For instance, Mtemi of Wanyamwezi, the Mtwa of Uhehe, the Nkonsi of the Wangoni, the Mangi of the Wachagga, all became Sultans. Chiefs thus gnawed at people's ethnic identification (ibid.). The diffusion of tribal leadership in this era served to restrict the incidence of nationalist resistance to colonial rule, events such as the Maji Maji uprising that was a major multi-ethnic (nationalist) violent resistance against the German colonial rule in Tanganyika (Harnevik et al., I988:I2).

While Germans imposed direct rule in Tanganyika, Zanzibar experienced indirect rule at the hands of the British colonial administration. In this regard, the British used administrative structures and officials in place under the Sultan of Oman in Zanzibar to exercise control. The British colonialists not only inherited the Sultan's bureaucracy but also used his language (Swahili) in local administration (Coulson I982:4I). Afterwards, the British replaced the Sultan's officials with British officials and appointed young African graduates from various ethnic groups to hold middle and low ranking positions, but retained the Swahili language (Iliffe, I979:208; Coulson, I982:42). The continuous use of Swahili led to the introduction of a national language that would facilitate inter-ethnic dialogue and the formation of a Tanzanian national identity. It is worth noting that Swahili belongs to no ethnic group in Tanzania and thus no ethnic group can use it to wield power or influence to gain political dominance (Omari, I995:28).

Economically, Tanganyika and Zanzibar differed: in Zanzibar the economy was quite divisive as indicated above, while in Tanganyika the Germans banked on a mixture of settler and plantation agriculture on the one hand, and cash-crop oriented peasant agriculture on the other. The settler economy in Tanzania did not reach the levels of land alienation seen in Kenya and Southern Rhodesia where the British colonialists established a strong settler and plantation agriculture (Coulson I982:40). Despite the different political and economic structures in Zanzibar and Tanganyika, colonialism in both states weakened the role of bona-fide pre-colonial traditional economic systems and ethnic authorities; and superimposed new ones with colonial assigned non-ethnic political, cultural and social bases. 


\section{The British colonial era (1920-1961)}

The British took over power from the Germans in Tanganyika in I920. As opposed to the Germans who ruled Tanganyika as a colony, the British ruled it as a Protectorate. ${ }^{\text {II }}$ Upon taking over, the British reinforced the existing political and economic structures in Tanganyika. However, in contrast to German direct rule, the British opted to adopt indirect rule, which meant the incorporation of indigenous Tanganyikan political systems into the colonial administration through the establishment of native authorities, which were a blend of a chief and a council, native courts and a native treasury (Iliffe, I979:319).

As a result of indirect rule, Tanzania experienced a social reorganisation in which the British and Tanzanians united to form a political order based on what Iliffe (I979:324) called "mythical history". In this reorganisation, whereas the Germans had exercised direct control, the British "invented" traditional chiefs and gave those chiefs indirect powers and authority (Mpangala I999:I5). Similarly, where the German had employed "semi-indirect" rule, the British enhanced the powers of the traditional chiefs and restored their traditional names of chiefly authority. Later, the British centralised ethnic group leadership and subsequently broadened and consolidated ethnic identities for the proper carrying out of colonial objectives by introducing a system where smaller chiefdoms were placed under "paramount chiefs" (Mpangala, I999:I7). Putting the smaller chiefdoms of the Chagga ethnic groups located around the Kilimanjaro Mountain under one Chief or "Mangi" in the Chagga language, the Mangi Mareale, provides a typical example of this process. Interestingly, these efforts were not grand enough to form an ethnic structure capable of making divisive minimum winning coalitions.

The colonial economy in British Tanzania had a bearing on the ethnic dynamics and resultant nationalistic politics. Economically, Tanzania was at the bottom of the British imperial pecking order in Africa because of its protectorate status which implies greater limitations that stood in the way of the kind of large scale economic transformations seen in formal colonies such as Southern Rhodesia and Kenya (Iliffe, I979:302). Apart from the time factor, Tanganyika was less well endowed economically compared to the likes of South Africa with its gold or Middle Eastern countries with their oil (Iliffe, I979:26I). In this regard, limited efforts were put into dividing Tanzanians for purposes of benefitting from resources. Efforts were limitied to linking Tanzania to Kenya which was Britain's economic mainstay in East Africa, and that was possible without politicising ethnic divisions. That is why the British settled for Area and Provincial administrative units above the chiefs and even allowed regional associations which were multi-ethnic. This was not the case in Kenya as administrative and associational life during colonialism was set along ethnically homogeneous lines. Chiefs in general detested the colonial arrangement as it undermined their power. Informed by the lessons of Maji Maji and the nationalist movement that is discussed below, chiefs covertly mobilised their followers to fight a war

II A Protectorate is a territory which is not formally annexed but in which, by treaty, grant or other lawful means, the Crown has power and jurisdiction. Tanganyika became a British Protectorate under the League of Nations after Germany lost the First World War and was stripped of the colonies it had before the war. 
against British colonialism and at the height of the struggle played an active role under TAA and TANU leadership. So chieftainship as a basis for ethnicity was strong in Kenya, while artificial and thus weak in Tanzania.

\section{The nationalist movement and socialist nation-building project}

The pre-colonial fluidity and decentralised ethnic characteristics coupled with the colonial processes of ethnic fragmentation and their use in perpetuating colonial exploitation paved the way for nationalistic ideas in Tanzania. The nationalist movement dexterously mobilised the major social forces in Tanzanian society and recorded a high degree of unity upon independence. The achievement of the nationalist movement in Tanzania was predicated on the collaboration of elites in the political arena (The Tanganyika African Association-TAA), trade union and cooperative movements, all gluing the Tanzanian citizenry together to fight colonialism (Coulson, I982:102; Klugman et al., I999:79). TAA and later Tanganyika African National Union (TANU) formed the base of the coalition of the three to mobilise the masses' fight for independence.

TANU was committed to the goal of independence and proclaimed its opposition to tribal, religious and racial salience in politics. The organisation of TANU that included elected and appointed leaders and its modus operandi, afforded it space to forge an inclusive coalition of elites and non-elites that surpassed ethnic, racial, religious and occupational divides in Tanzania. This is because the appointing authority - the country's founding father Mwalimu Nyerere - invoked a multi-ethnic approach to incorporate key figures from various ethnic groups into the nationalist movement (Omari, I995:26). According to Omari, key leaders of ethnic groups who joined TANU included Chief Fundikira of the Wanyamwezi, Chief Anna Gwassa of Kasulu, Chief Therea Ntare of Heru Kasulu, and Chief Kasusura of Rusubi-Biharamulo. TANU went beyond recruiting elites. Its inclusiveness went on to develop a powerful mass-based political party that mobilised thousands of peasants, workers and traders onto the course of national independence (Coulson, I982:II5; Iliffe, I979:536). TANU became so strong that even the colonialsponsored political parties-the United Tanganyika Party (UTP) and African National Congress (ANC) could not stop it from canvassing support pan-territorially (Klugman et al., I999:80; Coulson, I982:II5).

Upon securing independence Nyerere rallied Tanzanians together through homegrown socialist principles - Ujamaa. Ujamaa is well defined in the Arusha Declaration. ${ }^{\mathrm{I}}$ The Declaration essentially pinpointed the post-colonial government's commitment to building a just and democratic society, free of severe income inequalities, in which all Tanzanians would share the benefits of development (Pratt, I999:3). Nyerere himself spelt out the values and objectives of the society he envisioned: 
"... we want to create a socialist society which is based on three principles: equality and respect for human dignity; sharing of the resources which are produced

by our efforts; work by everyone and exploitation by none"

At its core Nyerere's ideal society was an avowal of the fundamental equality of all humankind and a commitment to the building of national social, economic and political institutions and processes, which would mirror and ensure such equality. Politically, however, it was a monolithic political dispensation proscribing competing political parties and instituting a range of measures: muzzling of civic organisations under the aegis of the TANU and later CCM and politicisation of public institutions through appointment of party cadres to key positions in the public service as well as the appointment of public servants to key political portfolios (Lupogo, 200I). In the same vein, Chiefdoms and Native Authorities which were parochial and set to meet the colonial interests in a divide and rule fashion were disbanded to make way for the creation of national institutions and minimising "institutional multiplicity" among the modern nation state and the traditional institutions (Coulson, I982:136). Rationalising this trend, Mwalimu Nyerere contended that realising nation-building and economic development required unity (Nyerere, I967:I57-58). In other words a pluralistic political dispensation at the time was a stumbling block towards attainment of the ideal society envisioned.

Nyerere's commitment to his ideal state forcefully downplayed the role of ethnic association in public life and instead accentuated a Tanzanian national identity (Miguel, 2004:337). For example, Nyerere relocated the capital of Tanzania from the coast city of Dar es Salaam to the more centrally-located Dodoma in 1973 , an act that confirmed his commitment to moving beyond colonially inherited localised identities and taking the state closer to all parts of the country to further the national project (Collier, 2009:67). Moreover, he also banned tribal unions and the mention of ethnic groups in newspapers and stopped collecting information on ethnic identity in national censuses (Tripp, 1999).

To uphold a sense of national identity and unity, the postcolonial state reinforced Swahili as a national language. It was also made the language of instruction and an examined $^{13}$ subject in primary and secondary schools respectively. Swahili was complemented by national cultural festivals and competitions in the creation of an overarching sense of identity. The government's policy of allocating students and teachers to boarding schools and other government officials outside their home of origin was a step in the same direction (Heilman \& John, 20I2:2). Other initiatives included compulsory military training that mingled youth from all over the country and political education that was meant to instil a sense of patriotism, nation-building and unity. (Lupogo, 200I; Green, 20II).

I3 Swahili is highly regarded in the Tanzanian education system. It is a compulsory subject for all students from the primary school level up to ordinary secondary school level (Form IV). To ensure that it is taken seriously, the education authorities penalise students who fail the subject in their Form IV national examinations. The penalty is quite severe as students with grade point average passes meant for the first division are dropped down to the third division. Other subjects with similar status are Mathematics, Civics and English. 
Economically, Tanzania opted at the time for policies designed to minimise socioeconomic differentiation and inequalities across sectors and individuals (Khan \& Gray, 2006:57). The choice was vital because the colonialists favourably distributed socio-economic infrastructure in the agriculturally productive areas compared to the unproductive ones which offered labour reserves. Unpacking the ethnic socio-economic differences in Tanzania, Nyang'oro, (2004:IO-II) points out that the Haya, the Chagga and the Nyakyusa ethnic groups are perceived as having enjoyed disproportionate educational advantages during the colonial epoch, which consequently led to an occupational advantage of the members of these ethnic groups in postcolonial Tanzania. In the same vein, Jerman (I997) argues that the Haya and Nyakyusa dominate white collar employment in Tanzania while the Chagga dominate private enterprise (Jerman, 1997). Jerman's contention reflects the view of most Tanzanians. However, these perceptions of prejudice and discrimination have never been strong enough to affect inter-ethnic relations in social and political domains. The reason for this is that the disproportionate benefits in question are a product of colonialism, whereas the socialist state has attempted to address the inequalities through equitable distribution of public goods (Nyang'oro, 2004:IO-II).

To better curb socio-economic inequalities, TANU decided to villagise Tanzanians and nationalise the major means of production and distribution. Villagisation meant to put together dispersed population in order to provide accessible and affordable social amenities. The project was useful as schools and health centres were built all over the nation and the level of literacy rose to $90 \%$ by I $_{9} 85$ (Wangwe, 2005:I3). The decision to nationalise the economy provided room for the equitable distribution of the country's economic proceeds and created employment opportunities for Tanzanians. In this regard, the equitable distribution of the wealth of the nation contributed to unifying Tanzanians. The current liberalisation reforms reversed the situation as the nationalised assets were privatised, a big blow to Ujamaa and the desire to keep divisive politics at bay. Still, ethnic salience in politics in Tanzania is low. The subsequent section addresses the question of why this is the case.

\section{Sustained nationhood under liberal reforms}

In the I990s, Tanzania embarked upon a process of furthering economic and political liberalisation. Economically, liberalisation destroyed the economic system that had given the state a commanding role in the management and running of the economy. The reforms essentially made the state revert back to its traditional functions - law and order, and leave the economy to be run by the market and private capital (Wangwe, 2005:13). Politically, the reforms replaced the monolithic political dispensation with a plural one through the re-introduction of multi-party politics which undermined CCM's uncontested monopoly in Tanzania's politics. This set-up sought to separate CCM from the government, the trade unions and cooperatives, and to grant both freedom of press and association (Tripp, 2000:I97). Equally, the reforms disentangled the security forces from active involvement in politics, hence cutting their ties with the ruling party. 
The re-introduction of multiparty politics in Tanzania raised the concern that ethnic sentiments would gain salience in Tanzania (Gasarasi, I997; Omari I997; Erdmann, 2002). The claims were understandable as such patterns are normal in other African countries such as neighbouring Kenya. Zanzibar's historical and socio-economic path as highlighted above also warrants the base for divisive politics. Indeed, in Zanzibar the concerns were vindicated mainly through the Pemba-Unguja ethno-regional divide that has clearly been repeated in the outcomes of all multiparty elections since I995. The case is different in Tanzania Mainland which is the focus of this article, as studies conducted immediately after the re-introduction of political pluralism substantiated that struggles for public resources and/or political office were not informed by ethnic divisions (Barkan, I994:I0; Hyden I994:79; Glickman 1995:289). Arguing in the same vein, Jerman (1997:34) vehemently contends that the implementation of political competition did not translate into political rivalry between ethnic groups in Tanzania. Taking a broader societal perspective Barkan (I994:9-IO) posits that the ethnic groups in Tanzania have never taken central stage in the struggles for political power, land, work or other resources. Focusing on political competition Erdmann (2002:28) asserts that political parties in Tanzania are not formed on an ethnic basis, nor have they covertly or overtly embarked upon an ethnic agenda. Providing a rationale to Erdmann's observation, Nyang'oro, (2004:48) and Weber (2009:4) express the view that courting voters through ethnic sentiments in Tanzania could not yield positive results because the pre-liberalisation politics blatantly denounced divisive politics and instilled the sense of nationhood. All arguments in this paragraph suggest that socialist principles and practices were strong enough to diffuse any form of divisive politics and sustain a path away from ethnicity becoming a salient factor in Tanzania's political life.

It is important to note that the ruling party CCM has retained its hold on power with a sound pan-territorial majority in all elections - presidential, parliamentary and civic. This explains why Kelsall (2003:58) argued that pluralistic politics in Tanzania has never weakened CCM's vice-like grip on the political system. One could say with confidence that CCM has maintained its de facto political monistic stature within the multiparty setup. The reasons behind CCM's triumph divide scholars. Some point to its incumbent advantage and lack of will to truly democratise (Makulilo, 2007) while others, more positively, attribute CCM's persistent electoral victories to path dependency following nation-building policies and the need for peace and tranquillity (Kelsall, 2003; O'Gorman, 20I2).

Both lines of thought make sense. The second is most relevant to our discussion. CCM has conservatively preserved with passion its broad-based nationalist inclusive posture. Its leadership has continuously been heterogeneous in its religious, regional, generational and ethnic identifications, and in its ideological persuasions (Kelsall, 2003:6I). The party culturally reflects the nation. The general public in fact attributes the country's relative state of peace to the party's conscious quest for national unity and the equitable distribution of the 'national cake'. These are values that both the Tanzanian state and its 
people feel proud of (O'Gorman, 20I2). Nyerere's ideal of umoja ${ }^{14}$, long permeated the postcolonial lyrics of popular Swahili hip hop music known as Bongo Flava (Stroeken, 2005). All elements are there to speak of a depoliticisation of ethnicity by the rulers and the ruled.

Yet, there is another side to the same story. Tanzania's associational life that has been severely crippled by subsuming the social and political forces under the ruling party in the name of unity, peace, tranquillity and creation of a socialist society as discussed above, is critical in explaining the nationalist path. The coalition of forces ensured a unified national outlook of CCM and denied opposition parties ready-made social bases (including ethnicity) on which they could have built. In the context of ethnicity, CCM has stigmatised as tribalist the opposition parties with seemingly strong local bases, thereby impeding their expansion into other areas (Kelsall, 2003:60). According to Kelsall, NCCR-Mageuzi, once a major contender for the presidency whose leader came from Kilimanjaro, has been a victim of this as CCM identified it as a 'Chagga' party. The UDP was accused of being a vehicle for Sukuma interests. Similar views label CHADEMA as a Chagga party. CUF, being strong in Pemba where over $98 \%$ of its inhabitants are Muslims, has been accused of being an instrument for Muslim interests. The interests in question mainly revolve around improving Muslims' access to formal secular education and lucrative political and professional positions. These have been meritocratically dominated by Christians due to their comparative academic superiority thanks to Christian missionaries' investment in education in the country since colonialism (Heilman \& Kaiser, 2002). The disproportionate access to education and political and professional positions between Christians and Muslims raises misunderstanding and sometimes public dissent but has not crystallised into a political salient trajectory in Tanzania (Heilman \& Kaiser, 2002).

The tribal and religious accusations were well articulated by CCM to maintain power as they linked them with the danger of civil wars and political unrest that has proven to be a constant threat in neighbouring countries including Kenya, Rwanda, Burundi and Congo. In the early multi-party election campaigns, CCM even broadcasted videos with genocidal contents on TV screens at campaign rallies to sway voters away from the claimed divisive parties. CCM's demonisation of its competitors for being ethnic or religious, and the support it earns for warning against the parties in question - parties that have never claimed to be ethnic in the first place - underline the value of national unity and peace in Tanzanian politics. Indeed, no speech given by a CCM leader or supporter has failed to mention CCM's role in the nation-building and the maintenance of peace, obviously a rare commodity in Africa. On the battlefield, therefore, every party overtly and covertly strives to ensure a national posture. The difference lies in the ability to exemplify such an outlook in a large country like Tanzania. CCM's incumbency gives it the advantage of being visible pan-territorially. Until now the weak and poorly resourced opposition cannot match it. 
CCM's nationalistic posture even made it possible to hold back heightened racial as well as anti-foreign hostilities in post-socialist Tanzania. This was laid bare when the opposition parties led by the Chair of the Democratic Party (DP) Reverend Christopher Mtikila mobilised support by denouncing Asian-Tanzanians - magabacholit5 and demanding preferential legislation for $w a z a w a^{16}$ (Aminzade, 2003). In his racial nationalistic plea for political support Mtikila targeted magabacholi as disloyal outsiders who are exploiting the nation for their own benefit at the expense of walala hoi ${ }^{17}$ (Campbell, I999). Mtikila's claims questioned a key element of liberal democracy, the protection of minority rights. In response, CCM denounced advocates of Mtikila's perspective as racist and shifted the focus of the indigenisation debate away from racial issues and magabacholi's control of the economy toward citizenship and issues of free trade, foreign investment, and foreign economic domination (Aminzade, 2003). In this spirit, CCM's government neutralised Mtikila's claims by implementing indigenisation measures targeting non-citizens and featuring anti-liberal economic policies, including tariff barriers, local content laws, and restrictions on property ownership (ibid.). The major decisions meant to neutralise Mtikila's plea was the appointment of Iddi Simba an advocate of indigenisation, though not as radical as Mtikila, and a businessman, to the Ministry of Trade and eventually enacting of an economic empowerment Act meant to support all Tanzanians regardless of their racial origin (Larson \& Aminzade, 2008). However, it is important to note that the wazawa, due to their number and economic backwardness, benefitted most from the microlevel empowerment measures. The indigenisation measures were implemented amid the danger of losing international support from foreign donors and international financial institutions that advocate liberalism (Aminzade, 2003).

Apart from CCM's measures that neutralised Mtikila's indigenisation plea, the over-generalised nature of his claim labelling all Tanzanians of Asian origin as magabacholi regardless of their involvement in the business world raised eyebrows among critics. Also it camouflaged wazawa known to be involved in the looting of public goods either through their positions in public or private sectors. This critique partly explains the public outcry against mafisadi a terminology meant to include all looters of public goods regardless of their colour or origin.

\section{Tying the structural and path dependent arguments for depoliticised ethnicity}

The above analysis on the role of ethnic structure and historical analysis of depoliticised ethnicity in Tanzania allows us to draw some interesting lessons, the most remarkable being the way the structural and historical factors have complemented each other to create a broader understanding of the factors behind Tanzania's low ethnic salience

\footnotetext{
I5 Magabacholi is a term coined by Mtikila referring to thieves or looters of Tanzania's wealth. The terminology has its origin in the Indian word Choli which literally means thief. The vocabulary was meant to connote alleged exploitation of Tanzania's wealth by Asian Tanzanians through their businesses.

I6 Wazawa is a racial nationalist vocabulary for indigenous people singlehandedly coined by Mtikila to express his exclusive sense of authentic Tanzanian identity. Walala hoi is another terminology coined by Reverend Mtikila meaning downtrodden Black Tanzanians.
} 
in politics. In the first instance a critical analysis of the debate on ethnic structures influencing ethnic salience in politics led us to see how this influence depended on the actual potential of attaining the minimum winning coalition. In the analysis we saw how the porous and decentralised heterogeneous ethnic structures of the pre-colonial and colonial era were maintained and directed to meet the colonial exploitative agenda without developing a sufficiently distinct political visibility to attract ethnic salience. In this way Tanzania is an exception to the colonialist record. The trend continued in independent Tanzania. In multi-party Tanzania no attempts have been made by parties to play the ethnic card. As argued, it is structurally the case that even if populous ethnic groups united, they could not attain a minimum winning coalition. More importantly, a successful winning coalition in Tanzania requires a wide geographical coverage as the major groups are distributed over a wide area. Hence the coalition will have a national outlook; distribution of the spoils of the nation will reflect the grand coalition. This would nullify the parochial and antagonistic posture that ethnic salience in politics tends to portray. Is this sufficient to explain the absence of ethnic salience? Going beyond mere absence, we looked at the process of depoliticising ethnicity. A thorough historical analysis that considers the political, social and economic factors can usefully complement the structural argument.

Our path-dependent analysis suggested that the politics of pre-colonial to postcolonial Tanzania consistently harboured unifying sentiments within a decentralised structure. The pre-colonial structures that were fluid and boundless with less centralised administrations were the nucleus of ethnic cooperation without unification. The colonially manipulated ethnic identities never twisted the pre-colonial situation significantly and exploited all groups with a focus on economically productive areas rather than ethnic favouritism. Given also the lesser economic significance compared to other colonies such as Kenya, Tanzanians could present a unified block against their exploiter, instead of waging a war on two fronts against the perceived local beneficiaries of the colonial economy and their colonial master. In this regard, it was a blessing for Tanzania that the British regarded it as a mere supplement to Kenya, the colonial economic mainstay.

In addition, the cross-cutting tribal associations, districts and regions' administrative set-up coupled with the promotion of Swahili as a national language in the colonial era provided impetus to the nationalist movement and post-independent nation-building initiative. The inclusive nature of the nationalist struggle in Tanzania coupled with deliberate Ujamaa nation-building policies logically furthered the nationalist infrastructure set during colonialism. In the same vein the current state of limited ethnicity is predicated on the maintenance of the nationalistic ethos inherited after independence and reinforced throughout Mwalimu Nyerere's tenure. Central to this is the widely agreed necessity of maintaining peace and tranquillity, whose primary condition according to postcolonial political culture is the fight against discrimination of all kinds. 


\section{Concluding remarks}

The overall discussion shows that ethnic structures and socio-economic and political history can together provide a comprehensive analysis of factors behind depoliticised ethnicity. On the one hand, extreme ethnic heterogeneity in countries appears helpful rather than harmful in depoliticising ethnicity, since the existence of multiple ethnic groups poses a barrier to the collective action necessary to form a minimum winning majority and thus to motivate ethnic salience in politics. On the other hand, socio-economic and political events can intertwine and amount to providing a path away from politicisation of ethnicity. The less ethnically divisive colonial administration and the nominal economic value of Tanzania at the time, coupled with the extensive socialist nation-building project shaped a strong Tanzanian national identity. The nation-building economic policies stipulated that all Tanzanians work together and share the fruits of their labour. Politically, the muzzling of the political and social forces under one mass party established a unified and passive political orientation among Tanzanians. This left limited public space for ethnic politicisation. Equally, it helped to suppress real, perceived and/or manipulated forces of ethnic canvassing, which resulted in a more unified ethnically diverse pluralist polity. In other words, a strong national identity made it possible for otherwise distinct groups to share common goals, thus leading to greater unity.

The nationalist political culture entrenched in Tanzania through Ujamaa has been critical in navigating Tanzania away from politicisation of ethnicity and its most damning consequences - civil war. Conversely, and consolidating the observed path dependence, the reinforcing effect of peace on the nationalist culture helped to perpetuate nationalist culture. It is against this background that Tanzanians in the liberalised era - an era that proved a platform for division in other African states - disapprove of ethnic salience in politics.

In light of our analysis it is prudent to argue that unification of the extremely ethnically diverse structured Tanzanian polity coupled with perceived benefits of unity and peace contributed to the depoliticisation of ethnicity. Invoking ethnic salience in politics would be tantamount to Tanzanians betraying their own identity. Increasingly, however, nationalist political culture has to deal with differences in wealth accumulation and political affiliations. Whether the path is strong enough to survive these divisions in the future, only time will tell.

\section{References}

Aminzade, R.(2003). From Race to Citizenship: The Indigenisation Debate in Post-Socialist Tanzania, Studies in: Comparative International Development, Spring, 38(I), pp. 43-63.

Bakari, M. (200I). The Democratisation Process in Zanzibar: A Retarded Transition, Hamburg: Institute of African Affairs.

Barkan, J. (1994). "Divergence and Convergence in Kenya and Tanzania: Pressures for Reform", in: J. Barkan. (ed) Beyond Capitalism vs. Socialism in Kenya and Tanzania, Nairobi: East African Educational Publishers.

Bates, R. (1983). "Modernisation, Ethnic Competition, and the Rationality of Politics in Contemporary Africa", in: D. Rothchild. and V. Olorunsola. (eds.), State versus Ethnic Claims: African Policy Dilemmas. Boulder, Colorado: Westview Press. 
Berman, B. (1998). Ethnicity, Patronage and the African State: The Politics of Uncivil Nationalism, African Affairs, 97 (388), pp. 305-34I.

Bratton, M. \& Kimenyi, M. (2008). "Voting in Kenya: Putting Ethnicity in Perspective”, Afrobarometer Working Papers 95 .

Bratton, M, Bhavnani, R. \& Chen, T. (20II). "Voting Intentions in Africa: Ethnic, Economic or Partisan?" Afrobarometer Working Paper 127.

Brown, S. (200I). "Authoritarian Leaders and Multiparty Elections in Africa: How Foreign Donors help to keep Kenya's Daniel Arap Moi in Power", Third World Quarterly. 22(5), pp. 725-739.

Campbell, J. (1999). Nationalism, Ethnicity and Religion: Fundamental Conflicts and the Politics of Identity in Tanzania, Nations and Nationalism, 5 (l), pp. 105-25.

Cederman, L. \& Girardin, L. (2007). "Beyond Fractionalisation: Mapping Ethnicity onto Nationalist Insurgencies", American Political Science Review, Ior (I), pp. I73-185.

Chabal, P. (2009). Africa: The Politics of Smiling and Suffering, Scottsville: University of KwaZulu-Natal Press.

Collier, P. (2009). Wars, Guns and Votes: Democracy in Dangerous Places, New York: Harper.

Coulson, A. (1982). Tanzania: A Political Economy. Oxford: Oxford University Press.

Erdmann, G. (2002). "Tanzania: Informal and Formal Social Bases of Political Parties in Africa", German Overseas Institute Working Paper 7.

Fearon, J. \& Laitin, D.(2003). "Ethnicity, Insurgency and Civil War" American Political Science Review , 97(I), pp. 75-90.

Gasarasi, C. (1997). "The Role of Socio-Cultural Factors in the 1995 General Elections in Mainland Tanzania" in: S. Mushi. and R. Mukandala. (eds.) Multiparty Democracy in Transition.Tanzania's 1995 General Elections, Dar es Salaam: TEMCO.

Glickman, H. (ed.) (1995). Ethnic Conflict and Democratisation in Africa, Atlanta: The African Studies Association Press.

Green, E.(20II). "The Political Economy of Nation Formation in Modern Tanzania: Explaining Stability in the Face of Diversity" Commonwealth and Comparative Politics, 49(2), pp. 223-244.

Harnevik, J. (1993). Tanzania. The Limits to Development from Above, Uppsala: NordiskaAfrikainstitutet.

Heilman, B. \& Kaiser, P. (2002). "Religion, Identity and Politics in Tanzania", Third World Quarterly, 23(4), pp. 69I-709.

Heilman, B. \& William, J. (2012). "Countries at the Crossroads 2012: Tanzania”, Freedom house, accessed at http://www.freedomhouse.org/sites/default/files/Tanzania\%20-\%20FINAL.pdf on 26th June 2013.

Hyden, G. (1994). "Party, State and Civil Society." in: J. Barkan. (ed.) Beyond Capitalism us. Socialism in Kenya and Tanzania. Nairobi: East African Educational Publishers.

Illife, J. (1979). A Modern History of Tanganyika, London: Cambridge University Press.

Jerman, H. (I997). Between five lines: The Development of Ethnicity in Tanzania with Special Reference to the Western Bagamoyo District, Uppsala: Nordiska Africkainstitutet.

Kelsall, T. (2003). "Governance, Democracy and Recent Political Struggles in Mainland Tanzania", Commonwealth and Comparative Politics, 4I(2), pp. 55-82.

Khan, M \& Gray, H. ( 2006). "State Weakness in Developing Countries and Strategies of Institutional Reform Operational Implications for Anti-Corruption Policy and A Case-Study of Tanzania", commissioned paper DFID.

Kiondo, A. (200I). "Group Differences in Political Orientation: Ethnicity and Class." in: S. Mushi., Mukandala, R. and Mwesiga, B. (eds) Tanzania's Political Culture: A Baseline Survey, Dar es Salaam: REDET.

Klopp, J. (200I). Electoral Despotism in Kenya: Land, Patronage and Resistance in the Multi-Party Context, PhD Thesis, Montreal: Mc Gill University. 
Klugman, J., Neyapti, B. \& Stewart, F. (1999). Conflict and Growth in Africa, Vol.2: Kenya, Tanzania and Uganda. Paris: OECD.

Larson, E. \& Aminzade, R. (2008). "Nation-building in Post-colonial Nation-States: the cases of Tanzania and Fiji" International Social Science Journal, 59(192) pp. I69-I82.

Lemarchand, R. (1994). BURUNDI: Ethnocide as Discourse and Practice. Cambridge: Woodrow Wilson Center Press and Cambridge University Press.

Lupogo, H. ( 200I). 'Civil-Military Relations and Political Stability', African Security Review Io(I).

Mahoney, J. (200I). The Legacies of Liberalism: Path Dependence and Political Regimes in Central America, Baltimore: Johns Hopkins University Press.

Makoloo, M. (2005). Kenya: Minorities, Indigenous Peoples and Ethnic Diversity. Minority Rights Group International. Retrieved on June 3, 2009, from http://www.minorityrights.org/I05o/reports/kenya-minorities-indigenous-peoples-andethnic diversity.html

Makulilo A. (2007). “Tanzania: A De Facto One Party State?”, paper presented at the 2oth REDET RMC Workshop held in Council Chamber, University of Dar es Salaam on Ioth November, 2007.

Malipula, M. (2003). "Inter-Party Conflict: CCM and CUF" in Maliyamkono. T. and Kanyongolo. F. (eds) When Political Parties Clash, Dar es Salaam, TEMA Publishers.

Miguel, E. (2004). "Tribe or Nation? Nation Building and Public Goods in Kenya versus Tanzania", World Politics, 56 (3), pp. 327-362.

Mpangala, G. (1992). Major Issues in Tanzanian Economic History, Dar es Salaam, Dar es Salaam University Press.

Mpangala, G. (1999). Peace, conflicts, and Democratisation Process in the Great Lakes Region: The experience of Tanzania. Dar es Salaam: Institute of Development Studies, University of Dar es Salaam.

Mukangara, D. (2000). Race, Ethnicity, Religion and Politics in Zanzibar. in: Maliyamkono, T. (ed), The Political Plight of Zanzibar, Dar es Salaam: TEMA Publishers.

Mutua, M. (2008). Kenya's Quest for Democracy: Taming the Leviathan. London: Lynne Rienner Publishers.

Nyaluke, D. (2013). Explaining the basis of African regime legitimacy, democracy and polity dominance: The Case of Tanzania, PhD Thesis, Dublin City University.

Nyang'oro, J. (2004). Ethnic Structure, Inequality and Governance of the Public Sector in Tanzania, Geneva: UNRISD.

Ogot, B. A. (2005). History as Destiny and History as Knowledge: Being Reflections on the Problems of Historicity and Historiography, Kisumu: Anyange Press Limited.

Omari, C. (1995). "The Management of Tribal and Religious Diversity." in: C. Legum, and G. Mmari, G (eds.), Mwalimu: Influence of Nyerere, London, James Currey. (1997). "Factors Which Influenced Voters." in: C. Omari. (ed.) The Right to Choose a Leader: Reflections on the 1995 Tanzanian General Elections. Dar es Salaam: Dar es Salaam University Press.

Nyerere, J. (1967). Freedom and Unity. London: Oxford University Press.

O'Gorman, M.(2012). "Why the CCM Won't Lose: The Roots of Single Party Dominance in Tanzania", Journal of Contemporary Africa Studies, 30(2), pp. 313-333.

Posner, D. (2005). Institutions and Ethnic Politics in Africa. Cambridge: Cambridge University Press.

Pratt, C. (I999). Obituary: "Julius Kambarage Nyerere - 1922-1999: Reflections on his legacy" Southern Africa Report Archive, I5(I), p. 2I.

Schultz, E. (1984). From Pagan to Pullo: Ethnic Identity Change in Northern Cameroon. Africa, 54(I), pp. 46-64.

Stroeken, K. (2005). "Immunising strategies: Hip hop and critique in Tanzania". Africa, 75(4), pp. 488-509.

Tripp, A.M. (1999). "The Political Mediation of Ethnic and Religious Diversity in Tanzania" in: C. Young (ed.) The Accommodation of Cultural Diversity: Case Studies. London: Macmillan Press.

URT (I969). 1967 Population Census, Demographic Statistics. Dar es Salaam: National Bureau of Statistics. 
Wangwe, S. (2005). "Culture, Identity and Social Integration: The Tanzania Experience in Social Integration", A paper presented at the Conference on New Frontiers of Social Policy: Development in a Globalizing World, Arusha, Tanzania, I2-I5 December 2005.

Weber, A. (2009). "The Causes of Politicisation of Ethnicity: A Comparative Case Study of Kenya and Tanzania", Working Paper 47,Centre for Comparative and International Studies, Swiss Federal Institute of Technology and Zurich University.

Wembah-Rashid, J. (1975). "The Ethno-History of the Matrilineal Peoples of Southeast Tanzania", Acta ethnologica et linguistica, 32, Series Africana 9. 